\title{
PELATIHAN PENGOLAHAN KOLEKSI DALAM MENDUKUNG PENGEMBANGAN PERPUSTAKAAN DESA
}

\author{
Tjahjanulin Domai ${ }^{1}$, Niken Lastiti V.A. ${ }^{2}$, Anita Tri Widiyawati ${ }^{3}$, Aulia Puspaning Galih ${ }^{4}$ \\ ${ }^{1,2,3,4)}$ Universitas Brawijaya, Malang, Jawa Timur, Indonesia \\ 1*Email: ulin_domai@yahoo.co.id \\ ${ }^{2}$ Email: nik_fia@yahoo.co.id \\ ${ }^{3}$ Email: anitatriwidiyawati@ymail.com/anitatriw@ub.ac.id \\ ${ }^{4}$ Email: auliapuspagalih@gmail.com
}

\begin{abstract}
Community empowerment through the Village Library is a very important tool in increasing the information literacy of rural communities. In the management of the library, the collection is the main thing and human resources is very important in maintaining the existence of the library itself. Sub district Junrejo not yet have people who are able to give responsibility for developing and managing the village. Related to these things this dedication to provide training and assistance in processing library collection. The output targets of this devotion are: a) to enrich and add to the repertoire of concepts and theories about the processing of printed and non-printed materials; 2) developing models and strategies on collection management in the development of a village library; c) subdistrict officials and village offices have knowledge in development and have the ability to carry out library material processing activities; and d) communities with sub districts that can be used to develop education, reading interest, and information literacy. Training in this task is the employees of village and sub district offices and kindergarten teachers in Junrejo Sub district.the implementation method used is theory and practice. Based on the realization and problem solving that has been implemented shows that the overall activity of this devotion has been run in accordance with the objectives, targets, and benefits that have been planned. So that the employees of the sub district office, village office, and kindergarten teachers in Junrejo Sub district, Batu City get provisions to apply knowledge about community empowerment through village libraries and village library management.
\end{abstract}

Keyword: training, village library, library collection processing

\section{PENDAHULUAN}

Seiring dengan perkembangan teknologi, informasi merupakan salah satu kebutuhan pokok masyarakat. Masyarakat dituntut untuk semakin cerdas dalam mencari, memilih, mengolah dan menggunakan berbagai informasi di sekeliling mereka. Dan hal ini berdampak pada semakin vitalnya keberadaan perpustakaan di tengah-tengah masyarakat sebagai bagian dalam membangun peradaban manusia. Perpustakaan merupakan salah satu tempat yang menyediakan akses bahan bacaan, informasi, dan memupuk kegemaran membaca masyarakat. Selain itu menurut Supriyanto, sebagai upaya untuk mencerdaskan kehidupan bangsa dan menunjang sarana belajar, perlu adanya perpustakaan yang dapat memberikan pelayanan informasi yang tepat dan merata ke seluruh golongan dan lapisan masyarakat (Supriyanto, 2006:105). Perpustakaan merupakan sarana penyedia informasi dan pelestarian peradaban manusia yang dapat dijadikan sebagai media pendidikan, penelitian, pengabdian masyarakat, komunikasi ilmiah antargenerasi, dan lainnya (Paijo, 2006:13). Di sinilah kemudian yang menyebabkan keberadaan perpustakaan semakin tidak terelakkan ditengah masyarakat.

Salah satu jenis perpustakaan yang keberadaannya dekat dengan masyarakat adalah perpustakaan desa. Perpustakaan desa merupakan ujung tombak layanan 
perpustakaan yang dekat dengan masyarakat karena berada di lingkungan desa. Perpustakaan desa adalah perpustakaan masyarakat yang menjadi salah satu sarana pendukung dalam hal pendidikan dan informasi masyarakat desa serta menjadi bagian dari peningkatan pembangunan desa. Perpustakaan desa memiliki legalitas formal dalam pembangunannya berdasarkan Surat Keputusan Menteri Dalam Negeri dan Otonomi Daerah Nomor 3 Tahun 2001 tentang Perpustakaan Desa (Menteri Dalam Negeri dan Otonomi Daerah, 2001). Pembangunan perpustakaan desa diprakarsai oleh pemerintah desa. Pemerintah desa bertanggung jawab terhadap pendirian dan penyelenggaraannya sehingga dapat digunakan sebagai sarana pendukung pendidikan informal masyarakat yang menjadi salah satu bagian dari program pembangunan desa.

Salah satu kecamatan di Kota Batu yang berkeinginan untuk mengembangkan perpustakaan desa di wilayahnya adalah Kecamatan Junrejo. Kecamatan Junrejo merupakan kecamatan yang masuk dalam wilayah Kota Batu. Kecamatan ini terdiri dari tujuh desa. Ketujuh desa di kecamatan ini adalah Desa Beji, Desa Dadaprejo, Desa Junrejo, Desa Mojorejo, Desa Pendem, Desa Tlekung, dan Desa Torongrejo. Junrejo memiliki luas wilayah $26,23 \mathrm{~km} 2$ dan penduduknya berjumlah 58.000 jiwa. Secara administratif, Kecamatan Junrejo dikelilingi oleh kecamatan lainnya yang ada di Kota Batu. Di sebelah utara, Junrejo berbatasan langsung dengan Kecamatan Bumiaji. Sedangkan di sebelah timur, kecamatan ini berbatasan langsung dengan Kecamatan Dau, Kabupaten Malang. Di sebelah selatan, Junrejo berbatasan dengan Kecamatan Wagir, Kabupaten Malang.Lalu, di sebelah barat, kecamatan ini berbatasan dengan Kecamatan Batu.

Berdasarkan hasil pengamatan awal, Kecamatan Junrejo belum memiliki personel yang mampu diberikan tanggung jawab untuk mengembangkan dan mengelola perpustakaan desa. Padahal dalam upaya pengembangan sebuah perpustakaan, keberadaan SDM menjadi salah satu hal krusial yang harus tersedia. Terkait hal tersebut maka pengabdian ini dimaksudkan untuk memberikan pelatihan dan pendampingan dalam pengolahan bahan pustaka. Hal ini didasarkan pada pertimbangan bahwa Koleksi dalam sebuah perpustakaan merupakan suatu hal yang sangat sentral, karena koleksilah yang akan dilayankan di perpustakaan. Koleksi bahan pustaka merupakan nafas suatu perpustakaan disamping factor pendukung lain seperti: gedung, sumberdaya manusia, dana, dan pemakai. Kuantitas dan kualitas koleksi sangat mempengaruhi minat pemakai dalam pemanfaatan jasa perpustakaan (Lasa, 2000:1). Koleksi sangat diperhitungkan keberadaannya, karena menjadi komponen inti yang berada disuatu perpustakaan.Melalui koleksi dapat pula ditentukan jenis suatu perpustakaan, serta menjadi kekuatan dalam hal untuk memenuhi kebutuhan penggunanya. Seperti yang diungkapkan Sulistyo-Basuki (1991:427) bahwa tugas utama setiap perpustakaan ialah membangun koleksi yang kuat demi kepentingan pengguna perpustakaan.

Setiap perpustakaan tentunya mempunyai visi dan misi yang berbeda, namun dapat dipastikan bahwa perpustakaan dikatakan berhasil apabila banyak digunakan oleh komunitasnya. Salah satu aspek penting untuk membuat suatu perpustakaan banyak digunakan oleh komunitasnya adalah ketersediaan koleksi yang memenuhi kebutuhan pemustaka Untuk itu penyediaan koleksi di perpustakaan harus diperhatikan dengan baik, mulai dari perencanaan sampai pada evaluasi koleksi dan hendaknya koleksi yang tersedia adalah koleksi yang mendukung pencapaian tujuan didirikannya perpustakaan desa. Terkait hal tersebut, maka pelatihan pengolahan koleksi/bahan pustaka menjadi salah satu cara yang tepat untuk mengembangkan perpustakaan desa, mengingat di Kecamatan dan di desa belum memiliki tenaga pustakawan ataupun SDM yang paham tentang seluk beluk perpustakaan, termasuk terkait koleksi digital dan cetak. 
Dengan "Pelatihan Pengelolaan Perpustakaan Desa di Kecamatan Junrejo, Kota Batu" diharapkan peserta pelatihan mampu mengaplikasikannya dalam jangka panjang. Dengan kemampuan yang memadahi dalam pengelolaan perpustakaan, khususnya terkait pengolahan koleksi perpustakaan/bahan pustaka,diharapkan peserta mampu mengelola perpustakaan desa lebih baik dan dapat mewujudkan perpustakaan yang ideal, sehingga literasi dan pembangunan masyarakat di segala bidang menjadi meningkat. Pada pengabdian

\section{METODE PELAKSANAAN}

\section{Kerangka Pemecahan Permasalahan}

Terbatasnya pengetahuan Pemerintah Kecamatan dan Pemerintah Desa mengenai pengelolaan Perpustakaan Desa serta tidak adanya pustakawan yang bekerja pada Pemerintahan Kecamatan dan Pemerintahan Desa, khususnya di Kecamatan Junrejo, Kota Batu menjadi latar belakang terlaksananya pengabdian ini. Perpustakaan desa/kelurahan dari pengertian awam adalah perpustakaan yang dikelola secara mandiri oleh pemerintah desa/kelurahan yang berada di tengah msayarakat desa.Menurut Surat Keputusan (SK) Menteri Dalam Negeri dan Otonomi Daerah Nomor 3 Tahun 2001, perpustakaan Desa/Kelurahan adalah "perpustakaan masyarakat sebagai salah satu sarana/media untuk meningkatkan dan mendukung kegiatan pendidikan masyarakat pedesaan, yang merupakan bagian integral dari kegiatan pembangunan desa/kelurahan". Dari definisi tersebut menunjukkan bahwakeberadaan perpustakaan desa sangat penting peranannya dalam pembangunan masyarakat pedesaan dari segala bidang.

Pemerintah Kecamatan Junrejo, Kota Batu sedang dalam proses untuk mengembangkan Perpustakaan Desa pada seluruh desa di Kecamatan Junrejo. Sebagai langkah awal, Pemerintah Kecamatan Junrejo membuat suatu program Perpustakaan Desa percontohan dengan membentuk Perpustakaan Desa di Kantor Kecamatan. Setelah program Perpustakaan Desa ini pada dasarnya terdapat beberapa IPTEKS yang akan ditransfer pada mitra, yakni segala hal yang berkaitan dengan pengelolaan perpustakaan secara keseluruhan, yakni manajemen perpustakaan desa, pembinaan koleksi layanan perpustakaan desa, kerjasama perpustakaan desa, hingga pada penggunaan sistem otomasi perpustakaan. Agar pengabdian ini menjadi lebih fokus, untuk langkah awal pengabdian adalah pelatihan mengenai "Pengolahan Koleksi Perpustakaan".

percontohan ini berhasil, maka Pemerintah Kecamatan akan melanjutkan program pembentukan Perpustakaan Desa pada masing-masing Kantor Desa di seluruh wilayah Kecamatan Junrejo melalui Pemerintah Desa. Adapun kendala terbesar dalam pembentukan Perpustakaan Desa percontohan ini adalah terbatasnya pengetahuan mengenai pengelolaan perpustakaan desa, sehingga dibutuhkan pelatihan pengelolaan perpustakaan desa di Kecamatan Junrejo, Kota Batu. Adanya pengelolaan perpustakaan desa yang baiksangat menentukan keberhasilan layanan yang diberikan oleh perpustakaan desa kepada masyarakat. Oleh karena itu, dibutuhkan solusi yang tepat untuk mendorong peningkatan kualitas dan keterampilan personel Pemerintah Kecamatan Junrejo dalam pengelolaan perpustakaan desa. Hal ini dikarenakan personel Pemerintah Kecamatan Junrejo menjadi model dalam pengembangan perpustakaan desa di seluruh wilayah Kecamatan Junrejo, Kota Batu. Adapun kerangka pemecahan dari pelatihan ini dapat dilihat pada Gambar 1.

\section{Khalayak Sasaran}

Proses rekruitmen peserta pelatihan dilakukan dengan cara:

a. Sosialisasi dan survei langsung pada lokasi yang akan menjadi sasaran dari kegiatan ini. 
b. Bekerja sama dengan Camat Junrejo, Kota Batu. c. Mendata Personel Pemerintah Kecamatan Junrejo, Kota Batu, personel Kantor Desa, serta guru TK di Kecamatan Junrejo.

\begin{tabular}{|l|}
\hline \multicolumn{1}{|c|}{ Peserta Pelatihan: } \\
1. Pegawai Pemerintah \\
Kecamatan Junrejo, Kota \\
Batu \\
2. Pegawai Kantor Desa di \\
Kecamatan Junrejo, Kota \\
Batu \\
3. Guru TK \\
\hline
\end{tabular}

\section{Gambar 1. Kerangka Pemecahan Pelatihan Pengelolaan Perpustakaan Desa (Pengolahan Koleksi) di Kecamatan Junrejo, Kota Batu}

\section{Metode Pelaksanaan Kegiatan}

Adapun metode yang digunakan dalam "Pelatihan Pengolahan Koleksi dalam Mendukung Pengembangan Perpustakaan Desa, yaitu.

\section{Teori}

Dalam pelatihan pengolahan koleksi perpustakaan/bahan pustaka bagi Personel Pemerintah Kecamatan Junrejo, Personel Kantor Desa dan Guru TK di Kecamatan Junrejo, Kota Batudibutuhkan dasar pengetahuan tentang pengolahan koleksi perpustakaan/bahan pustaka. Sehingga memudahkan peserta untuk memahami proses pembelajaran.

\section{Praktik}

Untuk menunjang pelatihan pengolahan koleksi perpustakaan/bahan pustaka bagi Personel Pemerintah Kecamatan Junrejo Personel Kantor Desa dan Guru TK di Kecamatan Junrejo, Kota Batu, maka dibutuhkan sebuah kegiatan pengalaman langsung yaitu berupa praktik. Dengan metode praktik maka peserta mampu melakukan simulasi dan menerapkan apa yang telah dipelajari dalam teori.

\section{Rancangan Evaluasi}

Evaluasi pelatihan akan diadakan setelah rangkaian acara telah selesai yaitu dengan dua cara:

a. Test teori yaitu berisi tentang soalsoalyang berkaitan tentang teori yang telah diajarkan.

b. Praktik yaitu dengan menilai hasil praktik peserta sesuai yang diajarkan. Indikator Keberhasilan antara lain:

a. Peserta pelatihan menguasai teori tentang pengolahan koleksi/bahan pustaka.

b. Peserta mampu mengolah koleksi/bahan pustaka dengan baik, dengan terlihatnya 
hasil koleksi perpustakaan yang siap untuk dilayankan.

c. Peserta mampu mengembangkan potensi diri.

d. Peserta dapat mengaplikasikan ilmu yang diperoleh dari pelatihan.

\section{HASIL DAN PEMBAHASAN}

\section{A. Hasil Pengabdian Kepada Masyarakat}

Pelatihan merupakan proses pendidikan jangka pendek yang menggunakan cara dan prosedur yang sistematis dan terorganisir. Para peserta pelatihan akan mempelajari pengetahuan dan keterampilan yang sifatnya praktis untuk tujuan tertentu. Selain itu, pelatihan juga merupakan suatu proses membantu orang lain dalam memperoleh keterampilan dan pengetahuan. Istilah latihan juga untuk menunjukkan setiap proses untuk mengembangkan bakat, keterampilan, dan kemampuan guru guna menyelesaikan pekerjaan-pekerjaan tertentu, dalam hal ini berkaitan dengan pengelolaan perpustakaan.

Pelatihan ini dilakukan dengan mengadakan penyuluhan/pelatihan yang dihadiri oleh pegawai Kantor Desa Torongrejo serta pegawai kecamatan Junrejo Malang.Pelatihan ini diikuti oleh 15 peserta, yang terdiri dari 9 orang pegawai Kantor Desa Torongrejo, 2orang pegawai dari Kelurahan Junrejo, dan 4 orang Guru TK. Secara umum, kegiatan pelatihan ini diawali oleh sambutan yang disampaikan oleh perwakilan dari kecamatan Junrejo Bapak Deny Ardian, S.AP.,M.AP., serta Sekretaris Desa Torongrejo Bapak Moh. Yakni, S.Pd.,M.Pd., dilanjutkan dengan penyampaian materi oleh tim pengabdian masyarakat tentang pemberdayaan masyarakat melalui perpustakaan desa, dan pengelolaan perpustakaan desa, baik secara teoritis dan praktis agar pegawai kecamatan dan kantor desa dapat lebih memahami pentingnya perpustakaan desa dalam peningkatan kualitas kehidupan masyarakat pedesaan. Berikut foto-foto hasil kegiatan pengabdian penyuluhan dan pelatihan perpustakaan desa di Desa Torongrejo, Kecamatan Junrejo. Sambutan perwakilan dari kecamatan dan kantor dapat dilihat pada Gambar 2. Pelatihan oleh tim pelaksanaan pengabdian kepada masyarakat bagi pegawai kantor desa dapat dilhat pada Gambar 3.

\section{B. Pembahasan \\ 1. Pemberdayaan Masyarakat melalui Perpustakaan Desa}

Pada tahun 2014, tingkat kemelekhurufan masyarakat Indonesia mencapai 92,8\% untuk kelompok dewasa, dan 98,8\% untuk kategori remaja.Masalah bangsa kita saat ini bukan lagi tentang bagaimana masyarakat bisa membaca. Akan tetapi justru masalah dan tantangan terbesar yang saat ini dihadapi oleh bangsa kita adalah rendahnya minat baca. The World's Most Literate Nations (WMLN) merilis daftar peringkat negara-negara berwawasan literasi (Jhon W. Miller (Presiden Central Connecticut State University, New Britain) pada 61 negara dan hasilnya Indonesia menduduki peringkat kedua dari bawah. Wawasan literasi Negara Indonesia dapat dilihat pada Gambar 4.

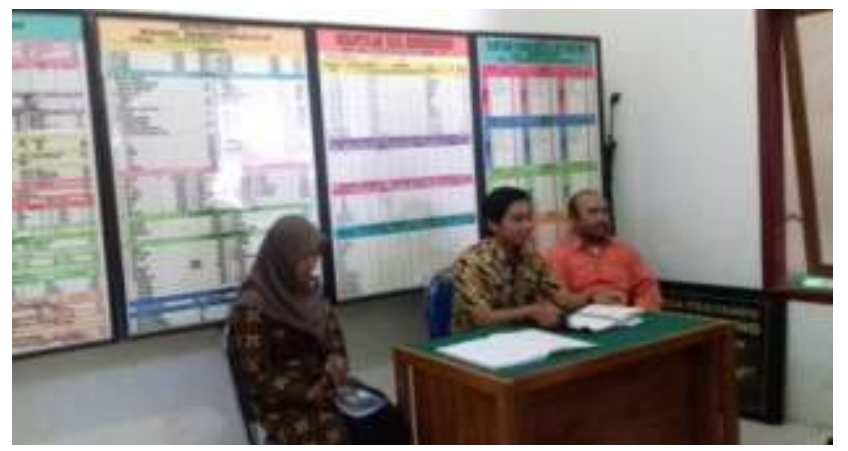

Gambar 1. Sambutan Perwakilan dari Kecamatan dan Kantor Desa (Sumber: doc. Pribadi, 2017) 


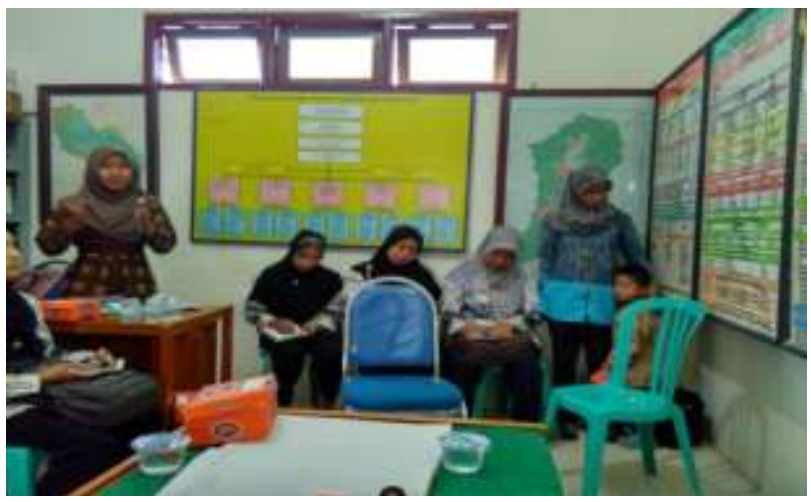

Gambar 2. Pelatihan oleh Tim Pelaksanaan Pengabdian Kepada Masyarakat Bagi Pegawai Kantor Desa dan Kecamatan, Serta Guru TK (1)

(Sumber: doc. Pribadi, 2017)

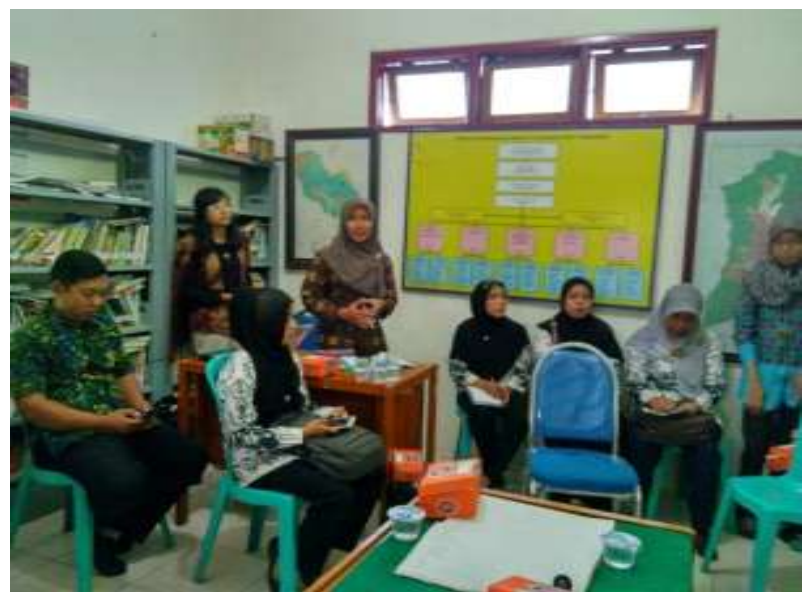

Gambar 3. Pelatihan oleh Tim Pelaksanaan Pengabdian Kepada Masyarakat Bagi

Pegawai Kecamatan, Kantor Desa, dan Guru TK (2)

(Sumber: doc. Pribadi, 2017)

HOW NATIONS RANKED
\begin{tabular}{|l|c|l|c|l|c|}
\hline Country & Rank & Country & Rank & Country & Rank \\
\hline Finland & 1 & Malta & 21 & Romania & 41 \\
\hline Norway & 2 & South Korea & 22 & Portugal & 42 \\
\hline Iceland & 3 & Czech Republic & 23 & Brazil & 43 \\
\hline Denmark & 4 & Ireland & 24 & Croatia & 44 \\
\hline Sweden & 5 & Italy & 25 & Qatar & 45 \\
\hline Switzerland & 6 & Austria & 26 & Costa Rica & 46 \\
\hline United States & 7 & Russia & 27 & Argentina & 47 \\
\hline Germany & 8 & Slovenia & 28 & Matuitius & 48 \\
\hline Latvia & 9 & Hungary & 29 & Serbia & 49 \\
\hline Netherlands & 10 & Slovak Republic & 30 & Turkey & 50 \\
\hline Canada & 11 & Lithuania & 31 & Georgia & 51 \\
\hline France & 12 & Japan & 32 & Tunisia & 52 \\
\hline Luxembourg & 13 & Cyprus & 33 & Malaysia & 53 \\
\hline Estonia & 14 & Bulgaria & 34 & Albania & 54 \\
\hline New Zealand & 15 & Spain & 35 & Panama & 55 \\
\hline Australia & 16 & Singapore & 36 & South Africa & 56 \\
\hline United Kingdom & 17 & Chile & 37 & Colombia & 57 \\
\hline Belgimm & 18 & Mexico & 38 & Morocco & 58 \\
\hline Israel & 19 & China & 39 & Thailand & 50 \\
\hline Poland & 20 & Greece & & Botswana & 61 \\
\hline
\end{tabular}

Gambar 4. Screenshot Wawasan Literasi Negara Indonesia (Sumber: The World's Most Literate Nations, 2014) 
Deklarasi Praha (Unesco, 2003) mencanangkan pentingnya literasi informasi (information literacy), yaitu kemampuan untuk mencari, memahami, mengevaluasi secara kritis, dan mengelola informasi menjadi pengetahuan yang bermanfaat untuk pengembangan kehidupan pribadi dan sosialnya. Kebutuhan literasi di era global ini menuntut pemerintah untuk menyediakan dan memfasilitasi sistem dan pelayanan pendidikan sesuai dengan UUD 1945, Pasal 31, Ayat 3 "Pemerintah mengusahakan dan menyelenggarakan satu sistem pendidikan nasional yang meningkatkan keimanan dan ketakwaan serta akhlak mulia dalam rangka mencerdaskan kehidupan bangsa, yang diatur dengan undang-undang."

Total desa pada tahun 2013 adalah sejumlah 79.095, sedangkan total perpustakaan desa atau kelurahan 24.745 (31,28\%). Dalam UU No. 43 Tahun 2007 pada bagian kedua pasal 16 disebutkan dengan jelas, bahwa Perpustakaan Desa merupakan salah satu jenis perpustakaan umum yang menjadi kewajiban pemerintah desa. Peran strategis perpustakaan desa, yaitu:

a. Pusat informasi dan ujung tombak gerakan literasi di masyarakat di desa.

b. Lokomotifpembangunan sumber daya manusia (SDM) yang kreatif, kritis, berdaya, dan mandiri melalui informasi.

Perpustakaan desa harus dikelola dengan kreatif, inovatif, dan profesional dengan beragam kegiatan. Kegiatan yang dilakukan tidak lagi pada kegiatan inti peminjaman-pengambalian buku, pengadaan buku dan pengolahan buku (inventarisasi koleksi, klasifikasi, pembuatan label buku, input data buku ke sistem otomasi perpustakaan) akan tetapi kegiatan yang berorientasi pada pemberdayaan masyarakat.

Misi perpustakaan desa/kelurahan menyediakan materi perpustakaan dan akses informasi bagi semua anggota masyarakat untuk kepentingan pendidikan, kebudayaan, ilmu pengetahuan, literasi informasi dan rekreasi. Membangun perpustakaan desa pun memiliki syarat dan aturan yang berlaku, berikut ini adalah syarat dan aturan mengenai perpustakaan desa:

1) Penyelenggaraan perpustakaan desa menjadi tanggung jawab pemerintah desa/kelurahan yang berkedudukan di desa/kelurahan dan dipimpin oleh seorang kepala.

2) Perpustakaan dibentuk oleh Kepala Desa/Lurah.

3) Pembentukan perpustakaan harus memenuhi syarat, memiliki koleksi, tenaga, sarana dan prasarana, dan sumber pendanaan.

4) Perpustakaan harus memiliki status kelembagaan yang dituangkan dalam Surat Keputusan Kepala Desa/Kelurahan dan diberitahukan kepada Perpustakaan Nasional.

2. Pengelolaan Perpustakaan Desa

a. Struktur Organisasi Perpustakaan Desa

Struktur organisasi perpustakaan Desa dapat dilihat pada Gambar 5.

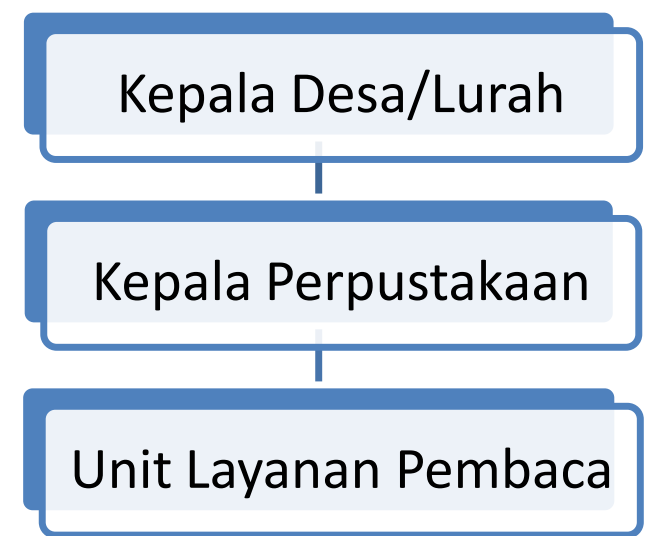

Gambar 5. Susunan Organisasi Perpurtakaan 
b. Sumber Daya Manusia Pada

Perpustakaan Desa

Pustakawan perpustakaan desa harus memiliki kualifikasi sebagai berikut:

1) Persyaratan mental. Pustakawan perpustakaan desa harus memiliki mnetal yang kuat sehingga dapat mengembangkan perpustakaan menjadi lebih baik lagi, misalnya melakukan program jemput bola terhadap masyarakat dalam rangka pengenalan perpustakaan kepada masyarakat luas.

2) Persyaratan pengetahuan. Pustakawan perpustakaan desa paling tidak memiliki pengetahuan dasar mengenai perpustakaan dan profesinya. Selain itu juga harus mengetahui potensi desa yang ada sehingga dapat dengan tepat memberikan informasi yang berguna bagi masyarakat desa.

3) Teknik pengelolaan perpustakaan: menata ruang perpustakaan, mengembangan koleksi, mengolah bahan pustaka, membimbing masyarakat

4) Adanya 2 kelompok kerja: pekerjaan yang bersifat teknis dan non-teknis perpustakaan. Pekerjaan teknis adalah pekerjaan yang berkaitan dengan pengolahan koleksi, sedangkan pekerjaan non-teknis adalah pekerjaan yang berkaitan dengan layanan pada pengguna perpustakaan desa.

5) Kepala Perpustakaan Desa adalah minimal lulusan SMP dengan ijasah diklat/kursus perpustakaan 700 jam

c. Anggaran Perpustakaan Desa pada:

Besarnya anggaran desa tergantung

1) Besar perpustakaan dalam arti luas ruangan, jumlah koleksi, pemakai, staf.

2) Skala layanan perpustakaan.

3) Jenis jasa perpustakaan .

4) Kelompok dan jumlah pemakai yang dilayani .

5) Jangkauan waktu. (biasanya 1 tahun).

Adapun sumber dana/pembiayaan Perpustakaan Desa/Kelurahan sesuai dengan lnstruksi Menteri Dalam Negeri Nomor 28
Tahun 1984 Tentang Pelaksanaan Penyelenggaraan Perpustakaan desa/kelurahan adalah berasal dari:

a) Swadaya masyarakat desa/kelurahan

Masyarakat dapat diberdayakan untuk membantu keberlangsungan pepustakaan desa dengan mengadakan program hibah buku dari masyarakat untuk masyarakat. Masyarakat dapat menghibahkan buku yang telah tidak dibaca lagi kepada perpustakaan desa untuk menambahkan koleksi.

b) Bantuan pemerintah (APBD/APBN)

Pemerintah desa dapat bekerja sama dengan pemerintah pusat agar mendapatkan dana tambahan untuk perpustakaan desa karena perpustakaan desa wajib dimiliki oleh setiap desa sesuai dengan undang-undang yang berlaku.

c) Lain-lain yang sah dan tidak mengikat

Pemerintah desa dapat bekerja sama dengan pihak lain, seperti perusahaan swasta untuk mendanai kegiatan perpustakaan desa karena setiap perusahaan memiliki CSR yang dananya digunakan untuk masyarakat sekitar. Dapat pula bekerja sama dengan perpustakaan kota atau perpustakaan daerah masing-masing agar dapat mengembangkan perpustakaan desa dengan lebih baik dari segi koleksi maupun dari segi pelayanan.

\section{d. Bangunan Perpustakaan Desa}

Bangunan perpustakaan desa dapat terletak satu gedung atau berdekatan dengan balai desa. INMENDAGRI No. 28 Tahun 1984 menjelaskan bahwa penyediaan tempat/ruangan dapat dilakukan dengan:

1) Menggunakan Balai Desa/Kelurahan atau Kantor LKMD.

2) Mengusahakan tempat/ruangan lain yang dianggap cukup memadai dan representatif.

e. Ruang Perpustakaan Desa

1) Ruang Pengolahan

Ruang kerja ini dipergunakan untuk melakukan berbagai kegiatan persiapan pelayanan seperti pengadaan, pengolahan, perbaikan buku, dll. Contoh bangunan perpustakaan Desa 1 dan Desa 2 dapat dilihat pada Gambar 6 dan Gambar 7. 
2) Ruang Pelayanan

Ruang Pelayanan terdiri dari tempat koleksi (rak-rak buku, majalah, surat kabar), layanan sirkulasi, tempat baca, dll.

\section{3) Toilet}

Denah perpustakaan Desa baik di dalam dan di luar perpustakan dapat dilihat pada Gambar 8.

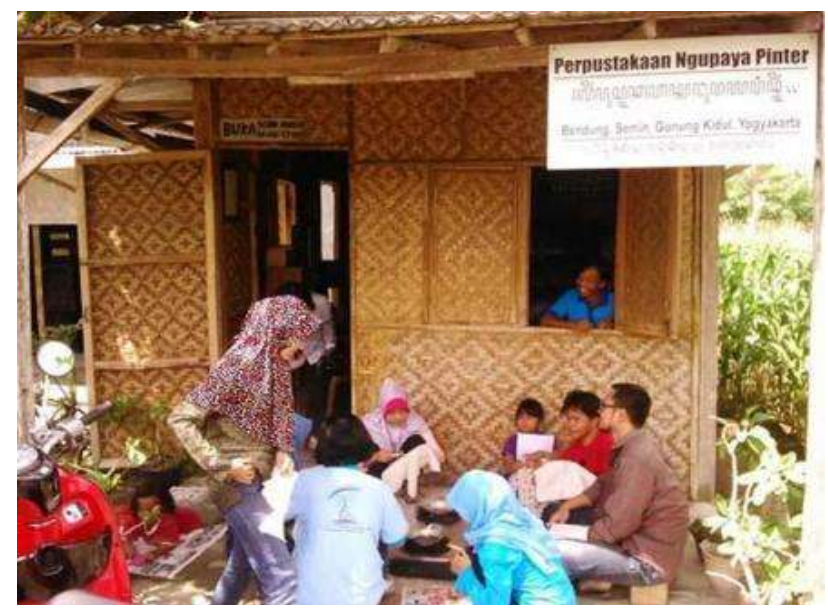

Gambar 6. Contoh Bangunan Perpustakaan Desa (2) (Sumber: doc. Pribadi, 2017)

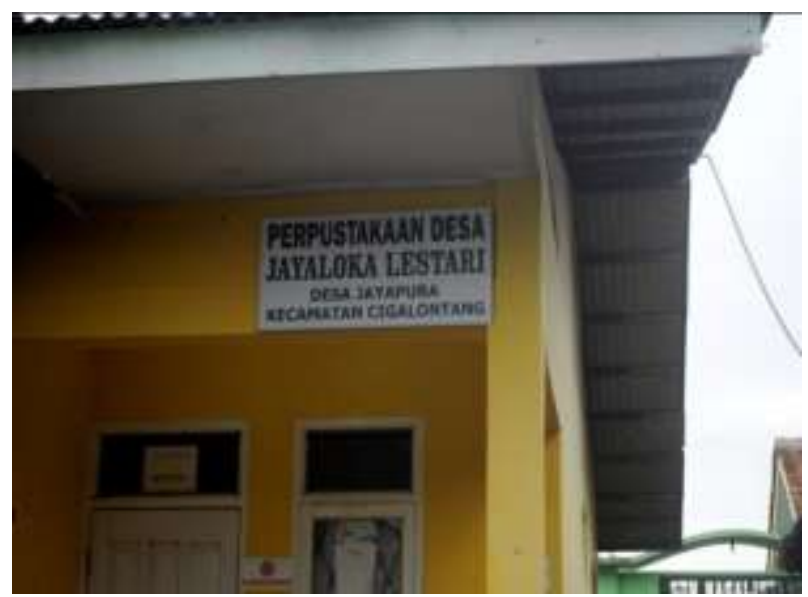

Gambar 7. Contoh BangunanPerpustakaan Desa (1) (Sumber: doc. Pribadi, 2017)

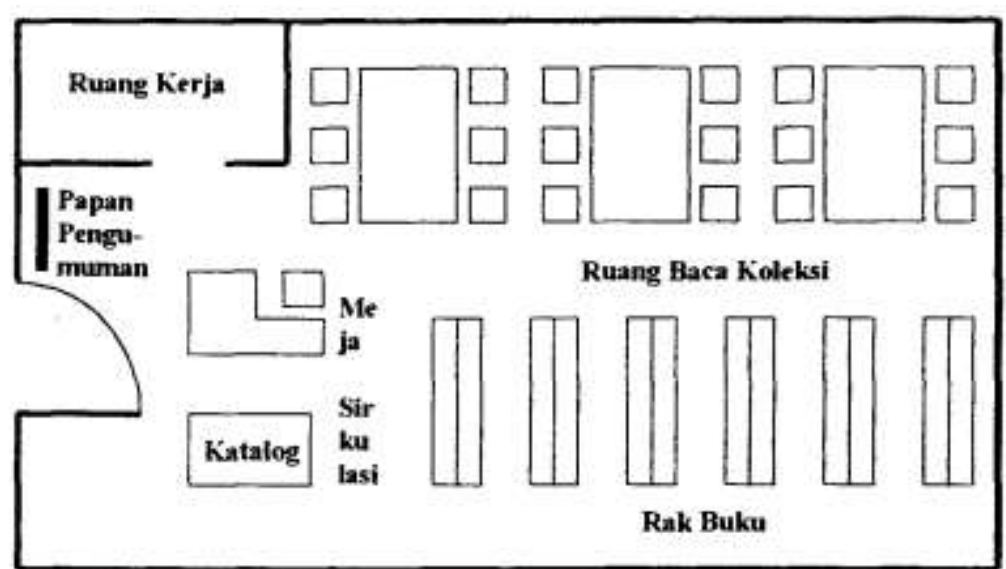




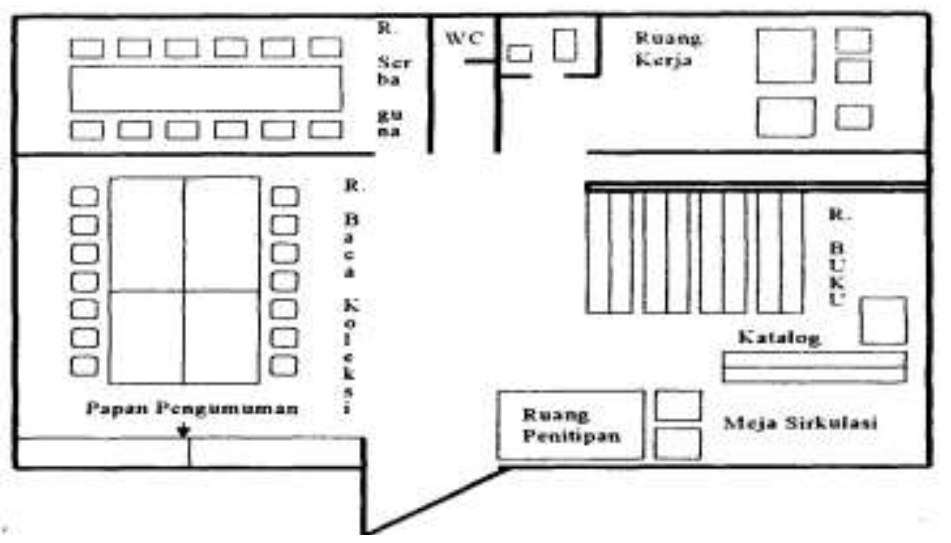

\section{Gambar 8. Denah perpustakaan Desa baik di dalam dan di luar perpustakan}

f. Perabotan dan Peralatan Perpustakaan Desa, yaitu: (1) Meja dan kursi kerja, (2) Buku induk, (3) Lemari, (4) Komputer, (5) Rak buku, (6) Stempel, (7) Alat tulis, (8) Jam dinding, (9) Rak brosur, majalah, koran, (10) Papan pengumuman, (11) Meja dan kursi pemustaka, (12) Karpet, (13) Kartu anggota, (14) Kartu peminjaman, (15) Buku sirkulasi

g. Koleksi Perpustakaan Desa, yaitu: (1) Buku (fiksi dan non fiksi) buku referensi (seperti kamus, ensiklopedia, bibliografi, indeks, abstrak, peta dan sebagainya); (2) Penerbitan pemerintah (pusat dan daerah), seperti himpunan peraturanperaturan pemerintah dan sebagainya; (3) Surat kabar; (4) Majalah, baik yang umum maupun yang khusus; (5) Karya alihan bentuk seperti film, slide, piringan hitam dan sebagainya.

Perpustakaan Desa yang baru didirikan diharapkan mempunyai koleksi dasar sekurang-kurangnya 1000 judul (2500 eksemplar). Adapun komposisi jenis koleksi yang dimiliki Perpustakaan Desa seyogyanya adalah dengan perbandingan non fiksi $60 \%$ dan fiksi $40 \%$. Dengan prosentase non fiksi lebih besar dimaksudkan agar masyarakat pemakai (Pedesaan) dapat memperluas pengetahuan umum dan keterampilan yang diperlukan dalam kegiatan sehari-hari. Upayakan ilmu pengetahuan praktis 60 - 70 $\%$ dari total buku-buku non fiksi.

Sesuai dengan Standar Nasional Perpustakaan (2011), perpustakaan desa memiliki jumlah koleksi sekurang-kurangnya meliputi: koleksi anak (500 judul); koleksi remaja/dewasa (1.000 judul); koleksi referensi anak (50 judul); koleksi referensiremaja/dewasa (50 judul); surat kabar yang dilanggan (1 judul); majalah yang dilanggan (1 judul); koleksi audio visual (1 judul).

\section{h. Pengadaan Koleksi}

Tentang pengadaan koleksi dapat dilakukan melalui pembelian. Pertukaran, hadiah atau sumbangan maupun titipan. Langkah-langkah pengadaan koleksi: pemilihan bahan pustaka atau koleksi (dibutuhkan alat bantu koleksi), pemesanan/pembelian koleksi, inventarisasi koleksi (cek fisik, stempel, pencatatan buku induk/kartu koleksi). Contoh buku induk koleksi di perpustakaan Desa hasil pengabdian kepada masyarakat dapat dilihat pada Gambar 9. Contoh kartu majalah dapat dilhat pada Gambar 10. Contoh kartu surat kabar yang terdapat pada perpustakaan hasil kegiatan pengabdian kepada masyarakat dapat dilhat pada Gambar 11. 


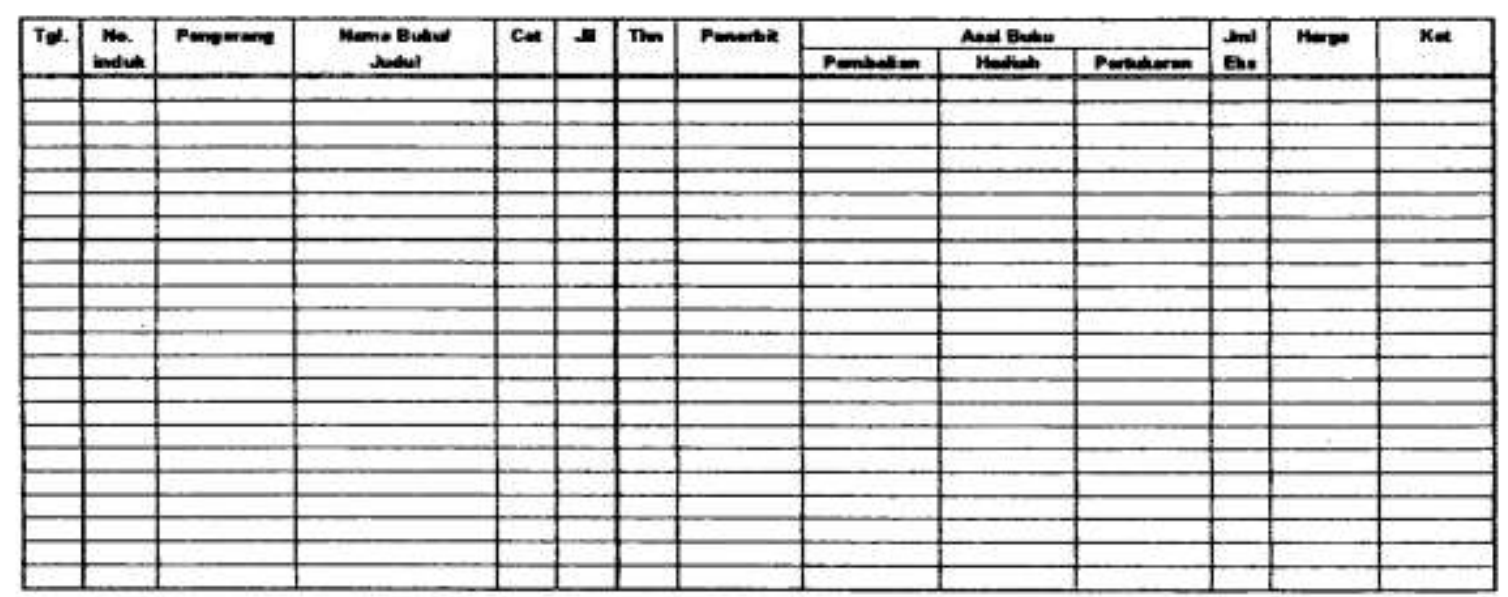

Gambar 9. Contoh Buku Induk Koleksi (Sumber: doc. Pribadi, 2017)

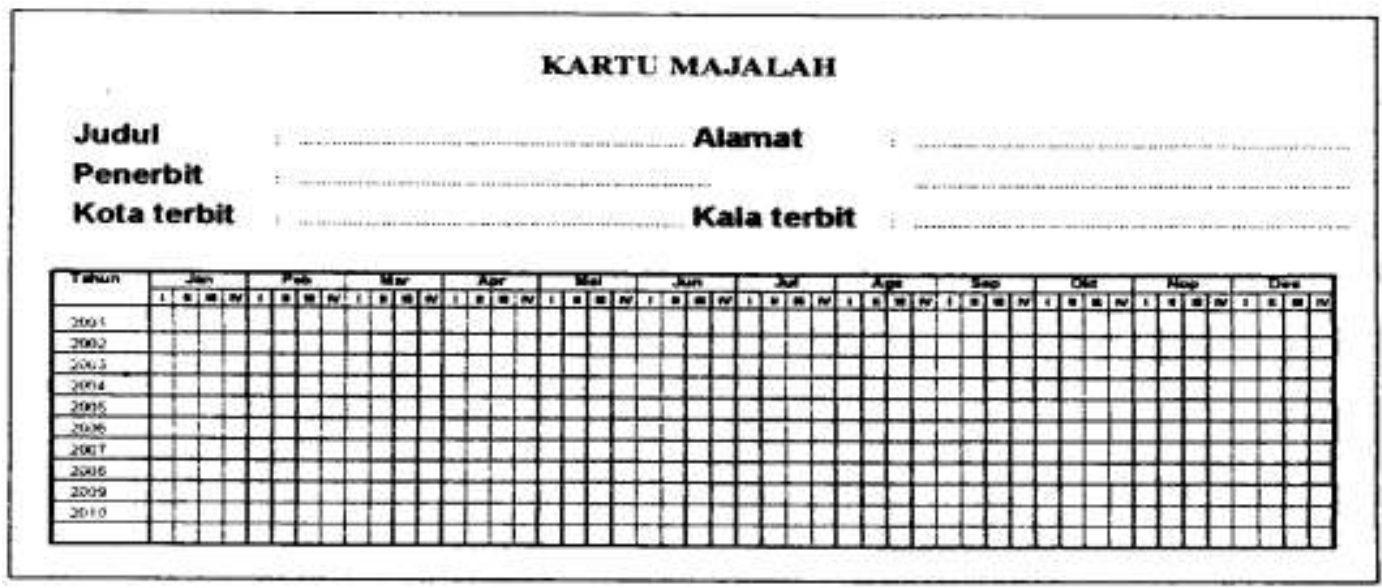

Gambar 10. Contoh Kartu Majalah (Sumber: doc. Pribadi, 2017)

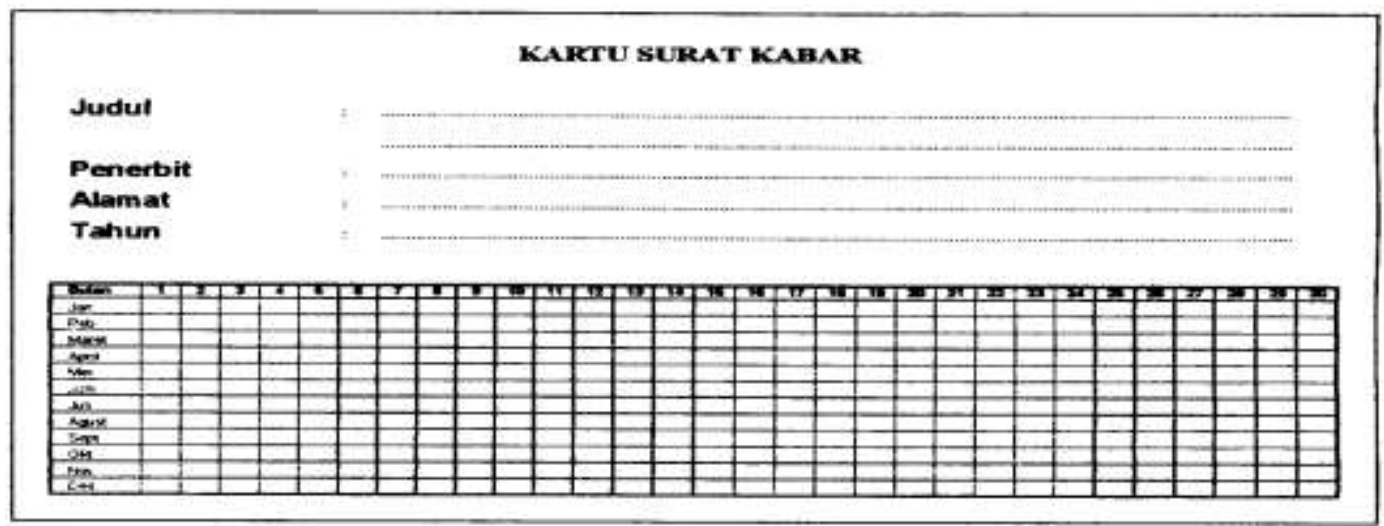

Gambar 11. Contoh Kartu Surat Kabar (Sumber: doc. Pribadi, 2017)

i. Layanan Perpustakaan Desa

1) Baca di tempat

2) Layanan sirkulasi

3) Aturan mengenai tata tertib perpustakaan (keanggotaan, jam buka min. 6 jam, peminjaman, kewajiban dan sanksi)

4) Pengunjung bebas memilih buku yang dikehendakinva. Apabila buku yang dicari tidak terdapat pada koleksi perpustakaan, maka dapat memilih alternatif buku lain yang sejenis atau bersamaan. Keuntungannya adalah tidak terlalu banyak memerlukan tenaga. Walaupun ada kerugiannya yaitu koleksi tercampur aduk oleh pengunjung serta kemungkinan buku hilang relatif lebih 
besar namun sistem inilah yang dianggap terbaik dan pada umumnya digunakan oleh Jenis perpustakaan yang melayani masyarakat umum (Perpusnas, provinsi dan perpustakaan perguruan tinggi serta sekolah) .

j. Perawatan dan Pengawasan Perpustakaan Desa

1) Pengendalian kondisi ruangan (cahaya kelembaban)

2) Untuk mengendalikan kondisi koleksi, perpustakaan menjaga temperatur, cahaya dan kelembaban ruangan.

3) Perbaikan bahan perpustakaan

4) Perpustakaan melakukan perbaikan bahan pustaka yang sudah rusak secara sederhana.

5) Pengawasan perpustakaan meliputi supervisi, evaluasi, dan pelaporan.

a) Supervisi dilakukan oleh kepala perpustakaan dan pemerintah daerah secara teratur dan berkesinambungan untuk menilai efisiensi, efektivitas, dan akuntabilitas perpustakaan.

b) Pengawasan perpustakaan dilakukan oleh masyarakat berupa saran perbaikan.

c) Perpustakaan menyediakan kotak saran untuk menampung pengaduan atau saran masyarakat.

d) Kepala perpustakaan menyelesaikan setiap saran atau pengaduan masyarakat sesuai kewenangannya.

k. Pelaporan Perpustakaan Desa, yaitu: (1) Pelaporan dilakukan oleh pimpinan perpustakaan dan disampaikan kepada Kepala Desa; (2) Pelaporan dibuat secara berkala dan mengacu pada tugas dan fungsi perpustakaan; (3) Pelaporan berfungsi sebagai bahan evaluasi sesuai dengan indikator kinerja.

1. Pengenalan Perpustakaan Desa, yaitu: (1) Buat perpustakaan semenarik mungkin; (2) Petugas yang ramah dan siap sedia; (3) Sistem jemput bola; (4) Membuat acara di perpustakaan; dan (5) Bekerja sama dengan pihak lain

\section{Klasifikasi}

Yaitu menentukan subjek yang dimiliki buku yang dinyatakan dengan notasi (angka klsifikasi). Notasi (angka klasifikasi) dicantumkan pada label buku yang ditempelkan pada punggung buku. Ini sangat penting untuk pengelompokan dan penyusunan buku di dalam rak buku agar mudah ditelusuri. Bila perpustakaan sejak lama telah mengolah buku atau bahan pustakanya. Agar tidak terjadi duplikasi terhadap pekerjaan kalsifikasi dan katalogisasi, sebelum buku diolah terlebih dahulu diadakan verifikasi (= melihat ke Kartu Shelf-list, apakah buku tersebut sudah pernah diolah).

Untuk memudahkan, setiap buku yang akan diolah diberi secarik kertas yang diberi nama "T. Slip" (Temporary Slip). Bagi buku yang sudah pernah diolah, cukup dicatat pada T. Slip notasi (call Number) dan No.Induk, Bagi buku yang belum pernah diolah, T. Slip dibiarkan kosong. Buku-buku yang berbahasa Indonesia yang jumlahnya kurang dari 25.000 cukup dengan menggunakan Buku Pedoman Klasifikasi yang berjudul "Pengantar Klasifikasi Perpustakaan Dewey" karangan Drs. Towa.P. Hamakonda MLS.

\section{Klasifikasibahan pustakadengan menggunakan DDC (Dewey Decimal Classification) \\ a. Pengertian klasifikasi}

1) Klasifikasi = classis (Latin), yakni: proses pengelompokan benda/entitas yang sama serta memisahkan benda/entitas yang tidak sama.

2) Pengelompokan yang sistematis: objek, gagasan, buku, atau benda-benda lain ke dalam kelas atau golongan tertentu berdasarkan ciri-ciri yang sama.

Contoh:

1) Bentuk fisik yang berbeda: penempatan dipisahkan (surat kabar, majalah, piringan hitam, microfilm, dan slides).

2) Penggunaan bahan pustaka: koleksi referensi, koleksi sirkulasi, koleksi anakanak, atau buku bacaan ringan. 


\section{b. Tujuan Klasifikasisebagai Sarana Pergerakan Pustaka:}

1) untuk memudahkan dan mendapatkan kembali dengan cepat dan tepat bila benda itu/hal itu diperlukan lagi.

2) membantu pemakai (pemustaka) mengidentifikasi dan melokalisasi sebuah dokumen berdasarkan nomor panggil (call number) atau sandi buku.

3) mengelompokkan semua dokumen sejenis menjadi satu.

4) menghemat waktu bagi pustakawan yang akan menambah koleksi dalam bidang tertentu yang dirasa kurang.

c. Jenis Penyusunan Pustaka

1) Penggolongan menurut besar-kecilnya ukuran kertas yang dipakai.

2) Penggolongan menurut masing-masing negara/tempat. Masing-masing negara/benua diberi kode sendiri.

3) Penggolongan menurut judul buku secara alfabetis.

4) Penggolongan berdasar nama pengarang secara alfabetis.

\section{d. Bagan atau Sistem Klasifiaksi}

Klasifikasi Persepuluhan Dewey

(DDC): menyusun semua subjek yang mencakup keseluruhan ilmu pengetahuan manusia ke dalam suatu susunan yang sistematis dan teratur, yang umumnya terdiri dari sejumlah kelas utama, yang masingmasing diperinci lagi menjadi bagian-bagian yang lebih kecil, menurut suatu urutan yang logis, dari yang bersifat umum ke yang bersifat khusus. Bagan DDC terdiri dari kelas utama, divisi, seksi, subseksi yang masih dapat diperinci lagi (Notasi atau simbol tertentu (dapat berupa angka, huruf, kombinasi angka dan huruf).

Apabila bagan klasifikasi menyusun dan memperinci ilmu pengetahuan ke dalam sejumlah subjek yang semakin lama makin khusus, maka indeks klasifikasi (bersifat relatif) menyusun suatu daftar subjek (yang diperinci ke dalam berbagai aspeknya) secara alfabetis, sehingga dengan demikian memberikan petunjuk yang memudahkan orang mencari subjek tertentu atau aspeknya di dalam bagan klasifikasi, berdasarkan notasi yang tertera di belakang tiap subjek atau aspeknya di dalam indeks. Notasi di dalam indeks bersifat relatif, artinya orang harus membandingkannya dengan notasi dalam bagan untuk mendapatkan yang paling tepat, karena notasi indeks merupakan petunjuk umum saja.

\section{e. Klasifikasi Persepuluhan Dewey}

DDC diciptakan oleh Melvil Dewey (1873), pertama kali diterbitkan tahun 1876. Dari edisi pertama yang hanya terdiri dari 52 halaman, kemudian terus dikembangkan. Edisi mutakhir yaitu edisi 20 (1989), saat ini yang terbaru adalah edisi 23. Unsur-unsur Pokok DDC

1) Sistematika, pembagian ilmu pengetahuan yang dituangkan ke dalam suatu bagan yang lengkap dan dilandaskan pada beberapa prinsip dasar tertentu.

2) Notasi, serangkaian simbol berupa angka, yang mewakili serangkaian istilah (yang mencerminkan subjek tertentu) yang terdapat dalam bagan. Dengan demikian setiap kelas, bagian, dan subbagian di dalam bagan mempunyai notasinya sendiri $=$ nomor kelas

3) Indeks Relatif, yang terdiri dari sejumlah tajuk dengan perincian aspek-aspeknya yang disusun secara alfabetis, dan memberikan petunjuk berupa nomor kelas, yang memungkinkan orang mencari tajuk yang tercantum dalam indeks pada bagan.

4) Tabel Pembantu, yang berbentuk serangkaian notasi khusus, yang dipakai untuk menyatakan aspek-aspek tertentu yang selalu terdapat dalam beberapa subjek yang berbeda. Terdapat 7 tabel pembantu: (1) Tabel subdivisi standar, (2) Tabel wilayah, (3) Tabel subdivisi kesusastraan, (4) Tabel subdivisi bahasa, (5) Tabel ras, bangsa, kelompok etnis, (6) Tabel bahasa-bahasa, dan (7) Tabel tentang orang/pribadi

\section{f. Penggunaan tabel 7}

1) Ditambahkan langsung

2) Tidak langsung. Tambahkan dengan notasi-08 yang diambil dari tabel 1-08 
Sejarah dan deskripsi berkenaan dengan jenis-jenis orang.

3) Golongkan orang yang dihubungkan dengan subjek tertentu dalam -092

4) Menyediakan kelas untuk karya umum, untuk menempatkan karya-karya yang begitu luas cakupannya, sehingga tidak dapat dimasukkan ke dalam salah satu kelas utama manapun. Demikian juga untuk karya tertentu yang bentuk penyajiannya lebih dipentingkan daripada subjeknya, seperti pada kesusastraan.

\section{Contoh cara mengklasifikasi}

Drama Jepang untuk Televisi

Disiplin ilmu: Kesusastraan Jepang

Bentuk penyajian: drama

Notasi klasifikasi:

895.6 (Kesusastraan Jepang)

-202 (drama untuk radio dan televisi) $\rightarrow 895.6202$

Tajuk subjek: drama/Jepang

Pada praktiknya, jika notasi klasifikasi dirasa terlalu panjang yang disebabkan judul buku mencakup ilmu terlalu kompleks walaupun notasi klasifikasinya sempurna akan tetapi jika ditempelkan pada punggung buku justru menjadi tidak praktis dan justru menjadi tidak efektif jika digunakan sebagai nomor panggil (call number), maka notasi klasifikasi sebaiknya dipotong/disingkat menurut disiplin ilmu akarnya.

\section{Contoh:}

Kenakalan Anak Remaja Keturunan

Yahudi di Mesir

Disiplin ilmu: Kriminologi (364)

$.3 \rightarrow$ para pelaku kejahatan, golongkan di sini psikologi kriminil termasuk kenakalan anak/remaja

Keturunan Yahudi $\rightarrow$ masuk dalam tabel 5 (ras, bangsa, kelompok etnis)

- $924 \rightarrow$ Israel, Yahudi

Mesir $\rightarrow$ Tempat $\rightarrow$ masuk dalam tabel 2 (wilayah)

- $621 \rightarrow$ Mesir (rumus $=$ sebelum T2 maka

notasi klasifikasi ditambah dengan 09

364.392409621

Tajuk subjek $=$ Kriminologi

\section{KESIMPULAN}

Berdasarkan realisasi dan pemecahan masalah yang telah dilaksanakan menunjukkan bahwa secara keseluruhan kegiatan pengabdian ini telah berjalan sesuai dengan tujuan, sasaran, dan manfaat yang telah direncanakan. Sehingga para pegawai kantor kecamatan, kantor desa, dan guru TK di Kecamatan Junrejo, Kota Batu mendapatkan bekal untuk menerapkan pengetahuan mengenai pemberdayaan masyarakat melalui perpustakaan desa dan pengelolaan perpustakaan desa. Dukungan Kecamatan dan Kantor Desa terhadap perpustakaan diharapkan dapat meningkat untuk membantu pemberdayaan masyarakat Desa Torongrejo Kecamatan Junrejo, sebagai salah satu tempat sasaran pengabdian perpustakaan desa percontohan pada khususnya.

Pelatihan pengelolaan perpustakaan ini juga diharapkan dapat bermanfaat bagi guruguru TK yang terletak di Kecamatan Junrejo untuk membenahi perpustakaan sekolah mereka. Meskipun koleksi dan pelayanan yang diberikan terdapat perbedaan antara masyarakat desa dan anak sekolah, tetapi dasar pengelolaan koleksi dan ilmu perpustakaan yang diberikan oleh tim pengabdian kepada masyarakat sama antara perpustakaan satu dengan yang lain.

\section{REFERENSI}

Hamakonda, Towa, P. dan Tairas. 2002. Pengantar Klasifikasi Persepuluhan Dewey. Jakarta: Gunung Mulia.

Lasa Hs. 2005.Manajemen Perpustakaan. Yogyakarta: Gama Media. Ar-Ruzz Media.

2000."Mengembangkan dan Mengevaluasi Koleksi Perpustakaan Perguruan Tinggi". Dalam Buletin FKP2T, Vol. V no.1-2 Th.2000.

Malhotra, Naresh K. 2009. Riset Pemasaran: Pendekatan Terapan Jilid 1. Edisi Keempat. Dialihbahasakan oleh Doddi Prastuti. Jakarta: PT. Indeks.

Menteri Dalam Negeri dan Otonomi Daerah.2001. Keputusan Menteri 
dalam Negeri dan Otonomi Nomor 3 Tahun 2001 tentang Penyelenggaraan Perpustakaan Desa/Kelurahan.

Paijo, Y. 2006.”Perpustakaan”. Dalam Media Informasi, Vol. XV no.3 Th.2006.

Purwono dan Sri Suharmini. 2010. Perpustakaan dan Kepustakawanan Indonesia. Jakarta: Universitas Terbuka.

Sulistyo-Basuki. 1991. Pengantar Ilmu Perpustakaan. Jakarta: Gramedia. 1992. Teknik dan Jasa

Dokumentasi. Jakarta: Gramedia.
Sutarno. 2006. Perpustakaan dan Masyarakat. Jakarta: Sagung Seto.

Suwarno, Wiji. 2010. Ilmu Perpustakaan dan Kode Etik Pustakwan.Yogyakarta: ArRuzz Media.

Theresia, Meak. 2011. Mewujudkan Desa Pintar melalui Perpustakaan Desa. Tersedia di http://www.batukar.info/ komunitas/articles/mewujudkandesapintar-melalui-perpustakaandesa. Diunduh tanggal 26 Juni 2017. 